\title{
Fenomen popularności utworów poetyckich Kazimierza Tetmajera wśród kompozytorów
}

\section{The Phenomenon of Kazimierz Tetmajer's Lyrical Pieces among Composers}

\begin{abstract}
The article discusses the problem of the popularity of lyrical pieces by Kazimierz Tetmajer among composers. The author reviews the factors which could have influenced the popularisation of selected lyric poems in the consciousness of musicians, and these include emotionality rooted in romanticism, the perfection of the poetic workshop and "musical" moulding of the linguistic material. The latter of these characteristics, analysed in the chapter "Tetmajer a muzyka" ("Tetmajer vs. Music"), is the central topic of this article. The author examines the "musicality" of Tetmajer's lyrical pieces on the level of the theme (where the issue of music terminology arises), sound ("tunefulness," "melodiousness," "rhythmicality") and construction (being inspired with a musical form of rondo in a poem Aniot Pański (Angelus)). It is probably Tetmajer's fascination with the art of sound, having its reflection in the linguistic material, which contributed to the composers' avid interest in his literary oeuvre.
\end{abstract}

Keywords: Kazimierz Tetmajer, "musicality" of poetry, Young Poland, solo song

Streszczenie: W artykule został podjęty problem popularności utworów poetyckich Kazimierza Tetmajera wśród kompozytorów. Autorka omawia czynniki, które mogły wpłynąć na upowszechnienie wybranych liryków w świadomości artystów zajmujących się sztuką dźwięków, a należą do nich: uczuciowość o genezie romantycznej, doskonałość warsztatowa poezji oraz „muzyczne” ukształtowanie materii językowej. Ostatni z wyróżników, poddany refleksji w części „Tetmajer a muzyka”, stanowi centralne zagadnienie poruszane w tekście. Autorka odnosi kwestię „muzyczności” liryków Tetmajera kolejno do płaszczyzny tematycznej (w obrębie której pojawia się problem wykorzystania muzycznej terminologii), brzmieniowej („melodyjność”, „śpiewność”, „rytmiczność”) oraz konstrukcyjnej (inspiracja formą ronda w wierszu Aniot Pański). To prawdopodobnie fascynacja twórcy sztuką dźwięków - znajdująca odzwierciedlenie w materii słownej - zadecydowała w głównej mierze o żywym zainteresowaniu kompozytorów jego dorobkiem poetyckim.

Słowa kluczowe: Kazimierz Tetmajer, „muzycznośc” poezji, Młoda Polska, pieśń solowa 
Termin „fenomen”, pojawiający się w tytule artykułu, wydaje się w kontekście omawianego problemu adekwatnym określeniem, bowiem do słów Kazimierza Tetmajera skomponowano łącznie 175 pieśni. Wśród polskich twórców podobnym rezonansem mogli poszczycić się jedynie Adam Mickiewicz i Adam Asnyk. W interpretowanym przypadku należy mówić o wyraźnie zarysowanej tendencji spadkowej - większość umuzycznień (ponad 100) powstała na przełomie XIX i XX wieku bądź w latach poprzedzających wybuch pierwszej wojny światowej i stała się udziałem czołowych kompozytorów tego okresu: Mieczysława Karłowicza, Karola Szymanowskiego, Władysława Żeleńskiego, Zygmunta Noskowskiego, Henryka Opieńskiego czy Feliksa Nowowiejskiego. W latach dwudziestych XX wieku zainteresowanie lirykami Tetmajera w środowisku muzycznym słabnie - powstaje wówczas tylko 36 pieśni solowych autorstwa twórców pozostających w zasięgu oddziaływań, w tym czasie już nieco anachronicznej, estetyki późnoromantycznej: Witolda Friemanna, Kazimierza Wiłkomirskiego, Jana Adama Maklakiewicza czy Wieńczysława Brzostowskiego. Jeszcze gorzej sytuacja prezentuje się w okresie po drugiej wojnie światowej, dominujące wtedy hasła wskazują lekceważący stosunek do wszystkiego, co „młodopolskie”. Umuzycznienia wówczas skomponowane (między innymi przez Piotra Rytla) włączane są do nurtu epigońskiego. Począwszy od lat siedemdziesiątych i osiemdziesiątych XX wieku daje się zauważyć wzrost zainteresowania poezją Tetmajera, znajdujący potwierdzenie w utworach Macieja Małeckiego, Krzysztofa Pendereckiego i Henryka Mikołaja Góreckiego, chociaż o fascynacji z przełomu wieków już nie może być mowy ${ }^{1}$.

Główną przyczyną tak radykalnego słabnięcia popularności poety w miarę upływu czasu jest silny związek jego dorobku z tematyką, wartościami, postawami preferowanymi w okresie Młodej Polski. Trudno zatem się dziwić, że kiedy nastroje i myśli pokolenia artystów młodopolskich straciły na aktualności - znikła też swoista „moda na Tetmajera”. Nie bez znaczenia pozostaje także kwestia uczuciowości typu romantycznego, wpływająca na zjawisko wzmożonego zainteresowania lirykami poety wśród kompozytorów preferujących tego rodzaju estetykę. Co oczywiste, w miarę przesuwania się w głąb XX wieku owa konwencja spotyka się z coraz mniejszą atencją twórców, których zaczynają pochłaniać bardziej awangardowe rozwiązania. Proces ten dobrze ilustruje ewolucja stylu Szymanowskiego, pozostającego początkowo pod silnym wpływem neoromantyków niemieckich (w trakcie komponowania cyklu z op. 2), a następnie (od około 1920 roku) podejmującego się interpretacji fragmentów utrzymanych w innym tonie emocjonalnym.

${ }^{1}$ Pełen wykaz kompozycji powstałych z inspiracji twórczością Tetmajera: zob. A. Nowak, Tetmajer [w:] Encyklopedia muzyczna PWM, t. 11, red. E. Dziębowska, Warszawa 2009, s. 70-72. Wartościowe opracowanie bibliografii muzycznej związanej z dorobkiem literackim innego polskiego poety - Juliusza Słowackiego, można znaleźć w pracy Agaty Seweryn Poezja „nutami niesiona". O muzycznej recepcji twórczości Juliusza Stowackiego, Warszawa 2008. 
Znamienny wydaje się dobór liryków z bogatego dorobku poety, na których skupiona została uwaga autorów opracowania muzycznego: zazwyczaj wybierali oni teksty refleksyjne (obfitujące w problemy egzystencjalne), utwory o tematyce miłosnej (ale nie erotyki), a ściślej - wspomnienia o miłości utraconej, a także wiersze wyrażające tęsknotę za krajem dzieciństwa, Arkadią. Nie sięgano natomiast po fragmenty typu opisowego, gdyż ten sposób obrazowania nie sprzyja interpretacji muzycznej. Odrzucano również wiersze powszechnie klasyfikowane jako impresjonistyczne ze względu na dostatecznie silne nasycenie ich różnymi efektami dźwiękowymi, warunkującymi z reguły ilustracyjną realizację kompozytorską. Ponownie warto w tym miejscu przywołać przykład Szymanowskiego, który zwykł dzielić teksty literackie na te łatwo poddające się umuzycznieniu $\mathrm{i}$ - tym samym - wzbogaceniu oraz te zawierające w sobie, niejako immanentnie, „muzyczność”, niewymagające dopełnienia w postaci „realnej” muzyki.

O popularności Tetmajera wśród twórców parających się sztuką dźwięków w epoce Młodej Polski zadecydowały nie tylko pokrewny typ duchowości i uczuciowości, ale także czysto warsztatowe walory jego poezji, które pozwoliły badaczom określić go mianem artysty słowa ${ }^{2}$. Na upowszechnienie tych liryków w dużym stopniu wpłynęło połączenie wirtuozerii w zakresie panowania nad tworzywem z przystępnością, zrozumiałością i sugestywnością języka. Podczas omawiania tej problematyki zwraca się uwagę na takie cechy techniki pisarskiej Tetmajera, jak swoboda i płynność toku poetyckiego, obfitość słownictwa (inflacja epitetów, a także - momentami wręcz manieryczne - stosowanie wyrażeń synonimicznych; wystarczy przywołać słynny wyimek: „Melancholia, tęsknota, smutek, zniechęcenie...”3), mistrzowskie posługiwanie się składnią, zamiłowanie do porównań (niekompatybilne z ówczesnym pobłażliwym stosunkiem do tego środka poetyckiego), których w III Serii Poezji Maria Podraza-Kwiatkowska znalazła około $70^{4}$. U Tetmajera mają one często charakter symboliczny, a więc służą jako pomost między opisem krajobrazu a pejzażem wewnętrznym:

Widzę kraj jakiś w oddali, w oddali,

Kraj z mgły przejrzystej, z rozkołysań sosny,

$\mathrm{Z}$ letnich południ i z porannej wiosny

$(\ldots)$

To kraj twej duszy 5 .

2 J. Krzyżanowski, Wstęp [w:] K. Tetmajer, Poezje wybrane, wstęp, oprac. J. Krzyżanowski, Wrocław 1968, s. LXXIX.

${ }^{3}$ K. Tetmajer, Zamyślenia [w:] tegoż, Poezje, seria 2, Warszawa 1901, s. 151.

${ }^{4}$ M. Podraza-Kwiatkowska, Symbolizm i symbolika w poezji Mtodej Polski. Teoria i praktyka, Kraków 1994, s. 277.

${ }^{5}$ K. Tetmajer, Dla rymu [w:] tegoż, Poezje, seria 3, Warszawa 1898, s. 86. Wszystkie wyróżnienia, jeżeli nie zaznaczono inaczej, pochodzą od autorki artykułu. 
Nad porównaniami górują w dorobku poety przenośnie, które jednak, wbrew tendencjom epoki, traktowane są dość konwencjonalnie. Badacze zwracają poza tym uwagę na Tetmajerowskie upodobanie do wprowadzania anafor oraz bogactwo wersyfikacyjne (cechy te w zasadniczy sposób wpływają na szeroko rozumianą „muzyczność” jego liryków), a także na szczególną dbałość o formę wiersza, przejawiającą się chociażby w starannej strofice czy w wyborze wyrafinowanych gatunków literackich: elegii, sonetu, hymnu, ody, ballady, anakreontyku.

W ramach przybliżania cech Tetmajerowskiego warsztatu warto się przyjrzeć środkowi dość odważnemu jak na ówczesne czasy - akcentującemu odległość, a nie podobieństwo znaczeniowe - który był pokłosiem oddziaływania symbolizmu na twórczość poety. Mowa o synestezji, zwanej również transpozycją wrażeń lub barwnym słyszeniem, polegającej na jednoczesnym występowaniu doznania słuchowego i wzrokowego. W praktyce realizowano ją poprzez nieoczekiwane (bo odsyłające do innych zmysłów niż te, z którymi zwykliśmy łączyć dane słowo) zestawienie epitetu ze sfery wrażeń zmysłowych z pojęciem abstrakcyjnym, co dobrze obrazują następujące sformułowania: „czerwone myśli”, „melodyjna melancholia”, „przepachnąca pieśń”. Lirykiem w sugestywny sposób ukazującym możliwości wyrazowe omówionego zabiegu w twórczości Tetmajera jest Trącona struna, w całości oparta na zasadzie powszechnych powinowactw:

Z głębi jeziora do księżyca

płynie melodia srebrnolica...

W głębinie lasu wśród paproci

szmer się w księżyca blasku złoci... ${ }^{6}$

Synestezję daje się rozpatrywać zarówno jako metaforę, jak i metonimię czy skróconą personifikację (w niektórych przypadkach), co dowodzi, iż konstrukcję tę znamionuje tendencja do eliptycznego traktowania wypowiedzi lirycznej, mająca na celu zaktywizowanie odbiorcy.

Całościowa ocena poetyki twórcy wymusza jednak uwzględnienie także głosów krytycznych, które wskazują na występujące w wierszach Tetmajera powstałych po 1900 roku „ezoteryczne rozmazanie”, „nieopanowanie słowne”, „rozpętanie alegorii”, „obfitość abstrakcji” i „patetyczne nazywanie, wyliczanie uczuć i nastrojów” wynikające z „zamiany techniki na metafizykę””.

${ }^{6}$ Tenże, Trącona struna [w:] tegoż, Poezje, seria 3, dz. cyt., s. 102.

7 J. Błoński, Kazimierz Tetmajer [w:] Literatura okresu Mtodej Polski, t. 1, red. K. Wyka, A. Hutnikiewicz, M. Puchalska, Warszawa 1968, s. 290. 


\section{Tetmajer a muzyka}

Nie ulega wątpliwości, że podstawowym czynnikiem decydującym o niebywałej popularności Tetmajera wśród kompozytorów z przełomu wieków było nasycenie jego liryki „muzyką”, której obecność daje się zauważyć (czy raczej usłyszeć) w obrębie różnych płaszczyzn utworu literackiego. Relacje między tymi dziedzinami sztuki w epoce Młodej Polski zyskują specyficzne oblicze, a jego przybliżenie wydaje się niezbędne do pełnego zrozumienia założeń przyświecających poecie. Można przyznać rację Andrzejowi Hejmejowi, który, omawiając interesujący nas problem, stwierdza, że o charakterze i stopniu wyrazistości muzycznych zagadnień w jakimś okresie literackim, poza ekspansywnością indywidualnych wysiłków artystycznych, decyduje „dyskurs kulturowo-interpretacyjny"8 (uwarunkowania filologiczne, estetyczno-filozoficzne).

Źródeł młodopolskiej supremacji świata dźwięków poszukiwać należy w filozofii, a konkretniej - u tak ważnego dla modernistów Arthura Schopenhauera. Przekonywał on, że muzyka jest najwyższą ze sztuk, gdyż istnieje jedynie w czasie (a nie w przestrzeni - jak inne dziedziny artystyczne) ${ }^{9}$, oraz że stanowi odbicie samej Woli, zatem mówi o istocie bytu. Wskazuje się ponadto na zapładniającą rolę idei Gesamtkunstwerk Richarda Wagnera, która zapoczątkowuje wielorakie dążenia do syntezy (jako wyrazicielki jedności egzystencji) u symbolistów (correspondance des arts, zabieg synestezji, powszechnej analogii, lejtmotyw itd.). Leszek Polony wspomina nawet o „Wagneriańskiej genezie doktryny symbolizmu" ${ }^{10}$, upatrując w koncepcji dramatu muzycznego podstawową dążność tego nurtu artystycznego - „pragnienie dotarcia poprzez słowa, obrazy, doznania zmysłowe do jakiejś ukrytej, pozazjawiskowej, niewyrażalnej pojęciowo treści, do idei, uniwersaliów, stanów duszy. Jest to pragnienie kontaktu z rzeczywistością idealną, absolutną" ${ }^{11}$.

W ówczesnych wypowiedziach na temat muzyki akcentuje się przede wszystkim jej asemantyczność, wieloznaczność, możliwość sugerowania i wyrażania (a nie informowania o...) niedookreślonych nastrojów i emocji czy moc ewokowania światów metafizycznych, a więc elementy inkorporowane do poezji

8 A. Hejmej, Muzyka w literaturze. Perspektywy komparatystyki interdyscyplinarnej, Kraków 2008, s. 41.

9 Tomasz Mann ujmuje tę kwestię następująco: „Muzyka budzi czas, a nas pobudza do najdoskonalszego odczuwania czasu”. Zob. K. Lipka, Styszalny krajobraz [w:] tegoż, Styszalny krajobraz, Warszawa 2005, s. 309.

${ }^{10}$ L. Polony, Muzyka w modernistycznej filozofii sztuki [w:] tegoż, W kręgu muzycznej wyobraźni. Eseje, artykuty, recenzje, Kraków 1980, s. 108.

${ }^{11}$ Tamże, s. 110. W tym kontekście warto przywołać opinię Krzysztofa Lipki na temat roli odwołań muzycznych w twórczości Rainera Marii Rilkego: „Najdrobniejsza aluzja, najkruchsza przenośnia muzycznie brzmiąca otwiera z nagła szerokie widnokręgi, w których dźwięk urasta w echo muzyki sfer, muzyki wieczności”. Zob. K. Lipka, dz. cyt., s. 306. 
symbolicznej. Sztuka dźwięków pomagała poza tym maksymalnie upodobnić ekspresję przeżycia wyjściowego do tej, którą chciano wzbudzić u odbiorcy, a był to naczelny postulat stawiany dziedzinom artystycznym w epoce Młodej Polski ${ }^{12}$. Proces zbliżania poezji do muzyki ilustrują rozmaite zabiegi: używanie muzycznej terminologii, stosowanie opisu literackiego odnoszącego się do sfery brzmieniowej (zdarzały się również próby przekładów muzyki na słowo), a także kształtowanie języka poetyckiego na wzór muzyki ${ }^{13}$.

Warto zacząć od kwestii terminologii muzycznej, którą inkrustowane są liryki Tetmajera. Jej obecność zaznacza się przede wszystkim w tytułach wierszy - odsyłających czy to do gatunków muzycznych: Ballada o..., Pieśn o..., Hymn do..., Oda, Czardasz, Marsz zbójecki, Elegia na wiolonczele, Preludia, czy to do jakiegoś określonego typu brzmieniowości i motywiki (motyw strun, dzwonienia i dzwonów): Trącona struna, Dzwony Św. Piotra w Rzymie, lub elementów dzieła muzycznego - Melodia mgiet nocnych. Ponadto treść licznych utworów obfituje w nazewnictwo związane z muzycznym instrumentarium pojawiają się między innymi: flet, skrzypce, wiolonczela, organy, harfa, fujarka, cytra czy forminga ${ }^{14}$.

Dla niniejszych rozważań szczególne znaczenie mają wymienione wcześniej Preludia, które nie tylko stały się znakiem rozpoznawczym poety, ale także pobudzały wyobraźnię wielu kompozytorów sięgających po liryki Tetmajera. Ten cykl, składający się z 40 wierszy (w pierwszej wersji z 1894 roku z 45), zainspirowany został - jak informuje Ferdynand Hoesick, adresat dedykacji oraz autor trzytomowej monografii poświęconej twórcy Mazurków - Preludiami Fryderyka Chopina ${ }^{15}$. Zdaniem Krystyny Zabawy istnieje prawdopodobieństwo, że dzieło Chopina wpłynęło na konstrukcję wierszy Tetmajera. Ewentualnych reminiscencji badaczka dopatruje się w zwartości oraz kontrastowym ukształtowaniu obu cyklów (naprzemienność „trybów” dur i moll u Tetmajera jest

12 Maria Podraza-Kwiatkowska w artykule $O$ muzycznej i niemuzycznej koncepcji poezji stwierdza: „Poezja zbliża się do muzyki w sposób maksymalny w tych okresach, w których najważniejszym problemem jest taka ekspresja przeżycia wyjściowego, ażeby wzbudzić identyczne przeżycie u odbiorcy”. Zob. taż, O muzycznej i niemuzycznej koncepcji poezji, „Teksty” 1980, nr 2, s. 96.

13 S.P. Scher proponuje następującą typologię: „muzyka słów” - związana z brzmieniowym kształtem tekstu literackiego, „struktury i techniki muzyczne” - odwołujące do konstrukcyjności muzycznej w literaturze, oraz „muzyka werbalna” - odsyłająca do wszelkich form literackiego tematyzowania muzyki. Zob. tenże, Literature and Music [w:] Interrelations of Literature, red. J.-P. Barricelli, J. Gibaldi, New York 1982; A. Hejmej, dz. cyt., s. 6.

${ }_{14}$ Dokładne wyliczenie można znaleźć w haśle Tetmajer autorstwa Anny Nowak. Zob. taż, Tetmajer, dz. cyt., s. 69-72.

15 F. Hoesick, Powieść mojego życia. Dom rodzicielski. Pamiętniki, t. 1, Wrocław-Kraków 1959, s. 439. W dorobku Tetmajera znajdują się jeszcze cztery inne utwory będące pokłosiem fascynacji dziełami autora Mazurków: między innymi Mazurek Chopina, Cień Chopina, Zamyslenia XVI. Zob. J. Bajda, The Place of Music in the Poetry of Kazimierz Przerwa-Tetmajer, „Interdisciplinary Studies in Musicology” 2011, nr 9, s. 197, 209. 
mało przekonująca, gdyż dur należy niemalże do wyjątków) ${ }^{16}$. Omawiając tę drugą wspólną cechę, Zabawa wskazuje opozycje w odniesieniu do czasu i przestrzeni występujące w lirykach poety: „tu” i „tam”, „teraz” i „kiedyś”, a także inne antynomie: jasność i ciemność, gorąco i zimno, dzieciństwo i młodość, raj i udręka. Nie ulega wątpliwości, że powyższe elementy uwypuklają podobieństwo między obydwoma cyklami, jednak wydaje się, że mówienie o przekładzie typu strukturalnego byłoby tutaj znacznym nadużyciem. Gatunek preludium implikuje pewien margines swobody w sposobie ukształtowania, stąd uchwycenie paraleli konstrukcyjnych na gruncie odmiennych dziedzin sztuki nie należy do zadań łatwych i w pełni rozstrzygalnych.

Jednym z istotniejszych dla wymowy całości utworów jest 7 wiersz cyklu Idzie na pola, który doczekał się wielu interpretacji kompozytorskich. Zabawa uznaje go za klucz do odczytania Preludiów. Uwagę autorki przykuwa zwłaszcza końcowy fragment liryku:

błękitna, cicha, skrzydlata

muzyka mojej duszy ${ }^{17}$.

Zwrot „muzyka duszy” obrazuje próbę przefiltrowania rzeczywistości zewnętrznej przez doświadczenie i indywidualną wrażliwość poety. Wiersz ten nawiązuje do wczesnego liryku Tetmajera - Cień Chopina ${ }^{18}$, co stanowi objaśnienie proweniencji tytułu cyklu. Zabawa eksponuje jeszcze inny niuans - zbieżność rytmu utworu z rytmem Preludium A-dur Chopina (też nr 7 w cyklu). Warto nadmienić, że liryk jest właściwie jedynym, w którym występuje najbardziej oczywiste nawiązanie do muzyki - poprzez jej stematyzowanie (przywołując określenie Henryka Andersa, to „hymn na cześć wszechobecnej muzyki” ${ }^{19}$ ).

Przez cykl przewija się także tęsknota za ludzkim głosem, którego nigdzie nie słychać, można więc tylko o nim marzyć:

Czasem, gdy długo na pół sennie marzę,

cudny kobiecy głos mię skądś dolata,

anielskie jakieś śpiewający pieśni,

piękniejsze niźli wszystkie pieśni świata... ${ }^{20}$

${ }^{16}$ K. Zabawa, Preludia - „muzyka (...) duszy” i zaduma „nad istnieniem” [w:] Poezja Kazimierza Tetmajera. Interpretacje, red. A. Czabanowska-Wróbel, P. Próchniak, M. Stala, Kraków 2003, s. 105-106.

${ }^{17}$ K. Tetmajer, Idzie na pola [w:] tegoż, Poezje wybrane, dz. cyt., s. 38.

${ }_{18}$ Muzycznej interpretacji tego liryku podjęli się między innymi: Władysław Żeleński, Stanisław Lipski, Juliusz Wertheim, Ryta Gnus i Witold Friemann. Zob. M. Gmys, On the Trail of a Trail, the Trace of a Trace: Kazimierz Przerwa-Tetmajer's "Cien Chopina" and its Compositional Interpretations, „Interdisciplinary Studies in Musicology” 2011, nr 9, s. 215-250.

19 H.P. Anders, Mieczystaw Kartowicz: życie i dokonania, Poznań 1998, s. 191.

${ }^{20}$ K. Tetmajer, Czasem, gdy dtugo na pót sennie marzę [w:] tegoż, Poezje wybrane, dz. cyt., s. 39. 
Fragment ten potwierdza tezę Anny Nowak głoszącą, że podmiot tekstowy (w tym wypadku - kobieta wyłaniająca się ze wspomnień „ja”) w wierszach Tetmajera to śpiewający swą pieśń pieśniarz, dla którego poezja jest „muzyką duszy" ${ }^{21}$. W Preludiach jednak głos bywa wzmiankowany głównie w kontekście wołania o miłość lub śmierć, nie służy więc eksponowaniu samej czynności śpiewania ${ }^{22}$. Trudno zatem mówić w tym wypadku o stematyzowaniu. Źródeł „muzyczności” cyklu należy doszukiwać się raczej w obrębie innych płaszczyzn, w warstwie językowej, która będzie przedmiotem rozważań w dalszej partii artykułu.

Aspekt foniczny dzieła literackiego budzi wiele kontrowersji wśród badaczy związków słowno-muzycznych. Dla niektórych jest on jedynym przejawem korespondencji między tymi sztukami (Stanisław Furmanik stawia tezę, iż jeśli już doszukujemy się czegoś na kształt „muzyki w dziele literackim”, to wolno ją tropić tylko w warstwie dźwiękowej utworu ${ }^{23}$ ), dla innych - wprowadzającym w błąd nieporozumieniem semantycznym (Tadeusz Szulc w pracy, która wywołała ożywioną dyskusję wśród komparatystów - Muzyka w dziele literackim, uznaje materiał porównywanych dziedzin za krańcowo różny i neguje prawdopodobieństwo występowania jakichkolwiek analogii między materią słowną a materią muzyczną). Zgadzam się z tezą o całkowitej nieprzystawalności szeroko pojmowanej „melodyjności” (a także „śpiewności”, „rytmiczności””) literatury do tej konstytuującej muzykę (zasadnicza różnica tkwi nie tyle w repertuarze dźwięków, ile w stosunku do dźwięku: w języku naturalnym istnieje bowiem poziom pośredni - słowa, a więc jednostki znaczącej ${ }^{25}$ ), jednak nie neguję możliwości upodobnienia brzmienia wiersza do właściwości akustycznych utworu muzycznego. Powołując się na Tadeusza Makowieckiego, uznaję, że:

mowa, zwłaszcza wiązana, składa się z elementów akustycznych, rozwijających się w czasie, bardzo licznych i różnorodnych, uporządkowanych w zespoły dźwiękowo-szmerowe, zrytmizowanych, ułożonych w wyraźne systemy dźwiękowe, nieraz

21 A. Nowak, Tetmajer, dz. cyt., s. 69.

22 „Postawą podmiotu lirycznego-poety jest przede wszystkim milczenie, a nie śpiew”. Zob. K. Zabawa, dz. cyt., s. 109.

${ }^{23}$ S. Furmanik, $Z$ zagadnień wersyfikacji polskiej, Warszawa 1956, s. 12.

${ }^{4}$ Jan Błoński w artykule Ut musica poësis? wskazuje na różnice między tymi pojęciami a trudną do zdefiniowania i używaną najczęściej w sensie przenośnym - „muzycznością”, polegającą jego zdaniem na „związku dynamicznej jedności z odraczaniem zrozumienia”. Nie sam zatem aspekt foniczny decyduje o „muzyczności”, lecz także specyficzna płynność i niedookreśloność znaczeń i obrazów, do której przede wszystkim dążyła poezja symboliczna. Zob. J. Błoński, Ut musica poësis? [w:] Muzyka w literaturze. Antologia polskich studiów powojennych, red. A. Hejmej, Kraków 2002, s. 132.

25 S. Dąbrowski, Muzyka w literaturze (Próba przeglądu zagadnień) [w:] Muzyka w literaturze..., dz. cyt., s. 156. 
bardzo urozmaicone, dające pole do gry wielu elementów, elementów pozwalających się ująć ściśle, a dających w rezultacie wrażenia estetyczne (często słuchowe) ${ }^{26}$.

Zaproponuję zatem wstępne założenie, iż to właśnie aspekt foniczny wierszy Tetmajera w głównej mierze zadecydował o ich szerokiej recepcji wśród kompozytorów.

Sfera brzmieniowa liryków poety jest niezwykle bogata i manifestowana w rozmaity sposób. Dbałość o nią przejawia się w stosowaniu „miar wyrównanych i zestrojonych"27 (będących rezultatem regularnego toku metrycznego), zamykaniu wersów rymami żeńskimi (wprowadzającymi miękkość zogniskowań), używaniu różnych odmian powtórzeń i paralelnych konstrukcji składniowych: anafor, epifor, refrenów (które przyjmują funkcje lejtmotywów i mogą być traktowane jako elementy nawiązujące do architektoniki muzycznej), jak tutaj:

Wykołysałem cię wśród fal mych snów, jak limbę gdzieś nadwodną, śniłem cię cichą i pogodną --

Ach! Jak mi żal, jak żal...

Na zieloności sennych hal, gdzie wiatr błękitne mgły rozpina, byłaś mi, dziewczę, tak jedyna -Ach! Jak mi żal, jak żal...28

albo w tym fragmencie:

Mów do mnie jeszcze... Za taką rozmową tęskniłem lata... Każde twoje słowo słodkie w mym sercu wywołuje dreszcze - mów do mnie jeszcze... ${ }^{29}$

Ponadto materia językowa utworu Tetmajera obfituje w zdania długie, gromadzące wyrazy pokrewne znaczeniowo i brzmieniowo oraz przynoszące efekt składni płynącej szerokimi frazami. Warto jednak zauważyć, że owa płynność bywa przez poetę urozmaicana, a nawet „zakłócana”, co wyklucza skrajną numeryczność liryku. W dorobku Tetmajera znajdują się również wiersze, których rytmika inspirowana jest wyraźnie twórczością ludową, czego przykładem

${ }^{26}$ T. Makowiecki, Poezja a muzyka [w:] Muzyka w literaturze..., dz. cyt., s. 11.

27 „Dowodzą jej stosowane przezeń miary, wyrównane i zestrojone, zgodnie z zamiarami autora”. J. Krzyżanowski, dz. cyt., s. LXXXVIII.

${ }^{28}$ K. Tetmajer, Zawód [w:] tegoż, Poezje wybrane, dz. cyt., s. 22.

29 Tenże, Mów do mnie jeszcze [w:] tegoż, Poezje wybrane, dz. cyt., s. 41. 
może być zastosowanie dwunastozgłoskowca żeńskiego, typowego dla krakowiaków i pieśni góralskich, w Pieśni o Jaśku zbójniku. Inne zabiegi uwypuklające „śpiewność” liryków poety i związane z tak zwaną instrumentacją głoskową to nagromadzenie głosek o wydłużonej emisji i grupowanie ich w odpowiednie ukształtowania brzmieniowe (asonanse, aliteracje itp.), a także częste użycie środków dźwiękonaśladowczych, multiplikujących efekty ciszy, szumów, szmerów oraz odgłosy akordów, chórów, grania i śpiewania. Bodaj najciekawszą propozycją poety, będącą rezerwuarem wspomnianych metod, jest wiersz Widziadto, w którym wrażeniom akustycznym, dostarczanym odbiorcy w warstwie semantycznej („róg”, „trąbiąc”, „dźwięk”), towarzyszy odpowiednie rozplanowanie fonicznej tkanki utworu - predylekcja do eksponowania samogłoski „u”, przypominającej dźwięk rogu. Wreszcie - prawdopodobnie najtrudniejsza do uzyskania w literaturze - „melodyjność” zostaje przez Tetmajera realizowana dzięki przewadze intonacji łagodnie wznoszącej się i opadającej, przyjmującej najczęściej kształt łuku lub linii falistej ${ }^{30}$.

W obręb zagadnienia „rytmiczości” włączane są - pełniące ważką funkcję w lirykach poety - pauza, zawieszenie głosu, cisza. Szczególną rolę prozodyjną i semantyczną zyskują one w cyklu Preludia, w którym pojawiają się podwójne pauzy i wielokropki. Te pierwsze wprowadzane są $\mathrm{w}$ celu podkreślenia istotnego słowa, wykrzyknienia i nadają wypowiedzi ton niepokoju, podczas gdy drugie następują często po zdaniach wykrzyknikowych lub pytających i wzmacniają ich wydźwięk dramatyczny. Zabawa zauważa, że wielokropek w finalnych utworach cyklu funkcjonuje jak fermata w muzyce, „przedłużając wartość ostatniego słowa, pozwalając mu wybrzmieć do końca, intensyfikując jego walor muzyczny, brzmieniowy właśnie" ${ }^{31}$. Podobnie obficie wykorzystane jest w Preludiach pole semantyczne „ciszy” i „milczenia” (wartościowane ambiwalentnie - jako element pożądany lub przyczyna cierpienia):

W wieczorną ciszę z daleka słyszę

szumiące cicho rzeki;

myśli me wolne, sennie kołysze

szum cichy i daleki ${ }^{32}$.

${ }^{30} \mathrm{Na}$ uwagę zasługuje definicja „gry intonacyjnej” zaproponowana przez Czesława Zgorzelskiego w artykule Elementy „muzyczności” w poezji lirycznej: jest to „falowanie wzniesień i spadków tonu, rytmiczne następstwo antykadencji i kadencji zdania - wraz z modyfikacjami takich "figur składniowych", jak np. wtrącenie, dopowiedzenie, komplikacje inwersyjne, konotacyjne, człony nawiasowe, urwania zdań, przeskoki itp. zjawiska - narzucone na siatkę uregulowań metrycznych”. Zob. tenże, Elementy „muzyczności” w poezji lirycznej [w:] Muzyka $w$ literaturze..., dz. cyt., s. 91.

${ }^{31}$ K. Zabawa, dz. cyt., s. 108.

${ }^{32}$ K. Tetmajer, W wieczornq ciszę [w:] tegoż, Poezje wybrane, dz. cyt., s. 40. 
W tym utworze cisza wzbogacona zostaje o efekt onomatopeiczny - szum, który łączony bywa w cyklu także z wiatrem czy smrekami:

Ku mej kołysce leciał od Tatr

o skrzydła orle otarty wiatr,

o limby, co się patrzą w urwisko -

leciał i szumiał nad mą kołyską ${ }^{33}$.

Dbałość o stronę dźwiękową Preludiów, przejawiająca się, poza wspomnianymi elementami, w zastosowaniu instrumentacji głoskowej, rymów, wykrzykników i zdań pytających o funkcji rytmizacyjnej, ma znaczenie nie tylko jako czynnik nastrojotwórczy, ale wspomaga wyrażanie problematyki egzystencjalnej, uwydatnia najgłębsze sensy liryków.

Odrębny problem stanowi próba przenoszenia konstrukcji muzycznych na grunt literacki. Zagadnienie to również - podobnie jak eufonia dzieła - spotyka się ze sceptycyzmem wśród badaczy. Michał Głowiński oznajmia stanowczo: „Jak się zdaje, nie sposób mówić o przenoszeniu zasad konstrukcyjnych form muzycznych w obręb wypowiedzi literackiej”34. Oponują także René Wellek i Austin Warren, zdaniem których powtarzanie i kontrast należą do repertuaru metod literackich, za nieuprawnione uznając łączenie tych zjawisk ze strukturami znamiennymi dla muzyki ${ }^{35}$. Owe opinie tracą jednak nieco na znaczeniu w obliczu dokonań celowo nawiązujących do tak wyrafinowanych form, jak fuga czy allegro sonatowe, spotykanych nawet w naszej rodzimej twórczości: u Marii Grossek-Korynckiej i Wacława Rolicza-Liedera. Pojawiają się głosy uznające próby tego rodzaju za chybione ${ }^{36}$, jednak fakt pozostaje faktem za pomocą takich środków literackich, jak powtórzenie, wariantowanie czy kontrast, autorzy ci uzyskują efekt, który, w mniejszym lub większym stopniu, upodabnia ich dzieła do kompozycji muzycznych. O ile w odniesieniu do Preludiów wysuwałam wątpliwości co do ich ścisłej przystawalności do cyklu op. 28 Chopina, o tyle słynny wiersz Tetmajera, Aniot Pański, budzi oczywiste konotacje z formą ronda za sprawą regularnie powracającego refrenu (lejtmotywu) oddającego nastrój wieczornej modlitwy:

Na Anioł Pański biją dzwony

Niech będzie Maria pozdrowiona,

Niech będzie Chrystus pozdrowiony...

33 Tamże.

34 M. Głowiński, Literackość muzyki - muzyczność literatury [w:] Muzyka w literaturze..., dz. cyt., s. 118 .

35 R. Wellek, A. Warren, Teoria literatury, tłum. J. Krycki, I. Sieradzki, M. Żurowski, Warszawa 1973, s. 175-176.

36 Zob. K. Wyka, Mtoda Polska, t. 1, Kraków 1987. 
$\mathrm{Na}$ Anioł Pański biją dzwony,

W niebiosach kędyś głos ich kona... ${ }^{37}$

Efekt „muzyczności” zostaje tutaj zmultiplikowany dzięki wprowadzeniu powtórzeń oraz ukształtowań onomatopeicznych - przywołania wyobrażenia słuchowego bijących dzwonów ${ }^{38}$, których rytmiczne uderzenia w warstwie językowej pomaga wyeksponować wiersz sylabotoniczny ze stałym zestrojem akcentowym.

Podsumowując zagadnienie popularności utworów poetyckich Tetmajera wśród kompozytorów, warto wymienić raz jeszcze czynniki, które w znaczącym stopniu ukonstytuowały to zjawisko: uczuciowość o genezie romantycznej ciesząca się zainteresowaniem artystów wyznających tę estetykę, doskonałość warsztatowa poezji oraz „muzyczne” ukształtowanie materii językowej, będące naczelnym postulatem symbolizmu - ważnego źródła inspiracji dla autora Cienia Chopina. Dla pełnej jasności dodam, że owa „muzyczność” nie powinna być rozumiana nadto dosłownie - realizacje Tetmajerowskie tchną bowiem muzyką jakby „utajoną”, wysubtelnioną i nie nazbyt nachalną. Jak wspomniałam, w Preludiach tylko jeden utwór nosi znamiona wyraźnego stematyzowania, mimo że wiele liryków z tego cyklu doczekało się interpretacji muzycznych. Warto odwołać się tutaj do trafnego komentarza Anny Nowak:

Kompozytorzy częściej wybierali wiersze, w których obrazy ewokowane słowem nie kojarzą się bezpośrednio z muzyką, muzykami, efektami muzycznymi. Działanie dźwiękiem, muzyką jest w tych tekstach pośrednie, jest to np. działanie ciszą, szumem itp.; nie sugeruje zatem kompozytorom stosowania efektów dźwiękonaśladowczych ${ }^{39}$.

Wyjątek od tej reguły stanowi Aniot Pański, którego refren niejako wymusza odczytanie typu ilustracyjnego, co zapewne zadecydowało o ujęciu go przez Karłowicza w formę melodeklamacji, nie zaś pieśni.

Ostatnie lata, przynoszące więcej utworów inspirowanych poezją Tetmajera (a nawet operę - O Zwyrtale Muzykancie, autorstwa Ryszarda Klisowskiego),

${ }^{37}$ K. Tetmajer, Aniot Pański [w:] tegoż, Poezje wybrane, dz. cyt., s. 58.

${ }^{38}$ Beata Obsulewicz w artykule $O$ Dzwonach. Tryptyku Kazimierza Przerwy-Tetmajera wskazuje na wykorzystanie w Tryptyku (w skład którego wchodzi Aniot Pański) efektu echa związanego z rozmaitymi powtórzeniami oraz motywem dzwonu, a także ściśle skorelowanego ze sferą muzyki. Nota bene, autorka ciekawie odczytuje budowę Dzwonów, łącząc ją z układem architektonicznym ołtarza otwartego lub zamkniętego. Zob. taż, O Dzwonach. Tryptyku Kazimierza Przerwy-Tetmajera [w:] Poezja Kazimierza Tetmajera..., dz. cyt., s. 295-310. O motywie młodopolskich dzwonów (także w kontekście utworu Aniot Pański) wzmiankuje również Marcin Gmys w książce Harmonie i dysonanse. Muzyka Mtodej Polski wobec innych sztuk, Poznań 2012, s. 299-304, 419-430.

39 A. Nowak, Liryki Tetmajera w pieśni postromantycznej i mtodopolskiej [w:] Poeci i ich muzyczny rezonans. Od Petrarki do Tetmajera. Studia, red. M. Tomaszewski, „Muzyka i Liryka. Zeszyty Naukowe Zespołu Historii i Teorii Pieśni”, Kraków 1994, s. 160. 
każą wierzyć, że dorobek ten ponownie wkroczy w szerszy obieg artystyczny i wzbudzi zainteresowanie kompozytorów. Nadzieją napawa rozwój gałęzi interdyscyplinarnych, bowiem badania z pogranicza sztuk wydają się niezbędne do właściwej oceny i zrozumienia dokonań Tetmajera. Na gruncie polskim propozycją tego rodzaju jest studium Justyny Bajdy - Poezja a sztuki piękne. O świadomości estetycznej i wyobraźni plastycznej Kazimierza Przerwy-Tetmajera ${ }^{40}$. Typowa dla okresu dwudziestolecia międzywojennego walka o „czystość” i autonomizację poszczególnych dziedzin artystycznych, która odcisnęła piętno na rezonansie twórczości poety, póki co ucichła.

\section{Bibliografia}

Anders H.P., Mieczystaw Kartowicz: życie i dokonania, Poznań 1998.

Bajda J., Poezja a sztuki piękne. O świadomości estetycznej i wyobraźni plastycznej Kazimierza Przerwy-Tetmajera, Warszawa 2003.

Bajda J., The Place of Music in the Poetry of Kazimierz Przerwa-Tetmajer, „Interdisciplinary Studies in Musicology" 2011, nr 9.

Błoński J., Kazimierz Tetmajer [w:] Literatura okresu Mtodej Polski, t. 1, red. K. Wyka, A. Hutnikiewicz, M Puchalska, Warszawa 1968.

Błoński J., Ut musica poësis? [w:] Muzyka w literaturze. Antologia polskich studiów powojennych, red. A. Hejmej, Kraków 2002.

Dąbrowski S., Muzyka w literaturze (Próba przegladu zagadnień) [w:] Muzyka w literaturze. Antologia polskich studiów powojennych, red. A. Hejmej, Kraków 2002.

Furmanik S., $Z$ zagadnień wersyfikacji polskiej, Warszawa 1956.

Głowiński M., Literackość muzyki - muzyczność literatury [w:] Muzyka w literaturze. Antologia polskich studiów powojennych, red. A. Hejmej, Kraków 2002.

Gmys M., Harmonie i dysonanse. Muzyka Mtodej Polski wobec innych sztuk, Poznań 2012.

Gmys M., On the Trail of a Trail, the Trace of a Trace: Kazimierz Przerwa-Tetmajer's "Cien Chopina” and its Compositional Interpretations, „Interdisciplinary Studies in Musicology" 2011, nr 9.

Hejmej A., Muzyka w literaturze. Perspektywy komparatystyki interdyscyplinarnej, Kraków 2008.

Hoesick F., Powieść mojego życia. Dom rodzicielski. Pamiętniki, t. 1, WrocławKraków 1959.

Lipka K., Styszalny krajobraz [w:] tegoż, Styszalny krajobraz, Warszawa 2005.

Makowiecki T., Poezja a muzyka [w:] Muzyka w literaturze. Antologia polskich studiów powojennych, red. A. Hejmej, Kraków 2002.

40 J. Bajda, Poezja a sztuki piękne. O świadomości estetycznej i wyobraźni plastycznej Kazimierza Przerwy-Tetmajera, Warszawa 2003. 
Nowak A., Liryki Tetmajera w pieśni postromantycznej i mtodopolskiej [w:] Poeci i ich muzyczny rezonans. Od Petrarki do Tetmajera. Studia, red. M. Tomaszewski, „Muzyka i Liryka. Zeszyty Naukowe Zespołu Historii i Teorii Pieśni”, Kraków 1994.

Nowak A., Tetmajer [w:] Encyklopedia muzyczna PWM, t. 11, red. E. Dziębowska, Warszawa 2009.

Obsulewicz B., O Dzwonach. Tryptyku Kazimierza Przerwy-Tetmajera [w:] Poezja Kazimierza Tetmajera. Interpretacje, red. A. Czabanowska-Wróbel, P. Próchniak, M. Stala, Kraków 2003.

Podraza-Kwiatkowska M., O muzycznej i niemuzycznej koncepcji poezji, „Teksty” 1980, nr 2.

Podraza-Kwiatkowska M., Symbolizm i symbolika w poezji Mtodej Polski. Teoria i praktyka, Kraków 1994.

Polony L., Muzyka w modernistycznej filozofii sztuki [w:] tegoż, W kregu muzycznej wyobraźni. Eseje, artykuty, recenzje, Kraków 1980.

Scher S.P., Literature and Music [w:] Interrelations of Literature, red. J.-P. Barricelli, J. Gibaldi, New York 1982.

Seweryn A., Poezja „nutami niesiona”. O muzycznej recepcji twórczości Juliusza Stowackiego, Warszawa 2008.

Tetmajer K., Poezje, seria 2, Warszawa 1901.

Tetmajer K., Poezje, seria 3, Warszawa 1898.

Tetmajer K., Poezje wybrane, wstęp, oprac. J. Krzyżanowski, Wrocław 1968.

Wellek R., Warren A., Teoria literatury, tłum. J. Krycki, I. Sieradzki, M. Żurowski, Warszawa 1973.

Wyka K., Mtoda Polska, t. 1, Kraków 1987.

Zabawa K., Preludia - „muzyka (...) duszy” i zaduma „nad istnieniem” [w:] Poezja Kazimierza Tetmajera. Interpretacje, red. A. Czabanowska-Wróbel, P. Próchniak, M. Stala, Kraków 2003.

Zgorzelski C., Elementy „muzyczności” w poezji lirycznej [w:] Muzyka w literaturze. Antologia polskich studiów powojennych, red. A. Hejmej, Kraków 2002. 